\title{
Job factors related to musculoskeletal symptoms among nursing personnel - a review
}

\author{
Marina Zambon Orpinelli Coluci, ${ }^{\mathrm{a},}$ and Neusa Maria Costa Alexandre ${ }^{\mathrm{a}}$ \\ ${ }^{a}$ Department of Nursing, Faculty of Medical Sciences, PO Box 6111, University of Campinas - UNICAMP, Zip \\ Code 13083-970, Campinas, SP, Brazil
}

\begin{abstract}
The study aimed to conduct a literature review as a step of the development of a new questionnaire about the nursing workers' perception of job factors that may lead to musculoskeletal symptoms. An information synthesis was achieved by collecting data from studies that fitted the search criteria. The results showed that despite the existence of several job factors related to musculoskeletal symptoms, no specific questionnaire that evaluates this relationship was found. Therefore, this literature review presents important topics for developing the first questionnaire to analyze work activities that may contribute to pain and discomfort among nursing personnel.
\end{abstract}

Keywords: work-related musculoskeletal disorders, job factors, nursing

\section{Introduction}

Health care workers are considered as a risk group to job-related musculoskeletal disorders, especially back pain $[9,13,44,45]$. Recent literature has demonstrated a high occurrence of musculoskeletal symptoms among nursing personnel $[1,16,21,26,36]$. Risk factors related to nursing work include biomechanical (risk movements and postures), environmental (workplace), organizational (lack of colleagues and inadequate equipments), and psychosocial factors (time pressure, low autonomy and competitiveness).

Nursing personnel perform various tasks that may cause musculoskeletal symptoms such as weight lifting, back stress, static postures, and awkward postures during specific procedures. Consequently, they classify their work as physically stressfull, especially when carried out in ergonomically unfavorable workplaces and under time pressure [22].

With the growth of the incidence of musculoskeletal symptoms related to work among nursing personnel, questionnaires that evaluate the risk factors that can lead to these symptoms may provide important data during ergonomic interventions.

The present study aimed to conduct a literature review about problematic work factors that may contribute to job-related pain and discomfort among nursing personnel. This review can be used as the first step for developing the questionnaire for nursing personnel.

\section{Methods}

The literature review was held in databases of Health Sciences as the Cochrane Library, SCIELO (Scientific Electronic Library Online), LILACS (Latin American and Caribbean Health Sciences Literature), MEDLINE (National Library of Medicine, USA), the International Nursing Index (INI), and the Cumulative Index to Nursing and Allied Health Literature (CINAHL).

The search was carried out for studies regarding musculoskeletal symptoms and related work activities among nursing personnel and for measuring instruments used in nursing.

\footnotetext{
${ }^{*}$ Corresponding author. E-mail: marinazo@fcm.unicamp.br.
} 
The keywords "work-related musculoskeletal disorders", "job factors", "nursing", "ergonomics", and "questionnaire" were used for this literature review and were chosen in the National Library of Medicine's Medical Subject Headings (MeSH = Medical Subject Heading Terms).

Since this review was one of the steps to develop a new questionnaire, an information synthesis was conducted.

\section{Results}

The literature review showed various studies regarding risk activities among nursing workers that can lead to musculoskeletal symptoms (Table 1).

Table 1

Studies regarding work factors that may contribute to job-related pain and discomfort among nursing personnel

\begin{tabular}{|c|c|}
\hline Authors & Job-factors related to musculoskeletal symptoms \\
\hline $\begin{array}{l}\text { Engels et al., 1996, Ando et al., 2000; Alexopoulos et al., 2006; } \\
\text { Yeung et al., } 2005\end{array}$ & Weight lifting \\
\hline $\begin{array}{l}\text { Smith et al., 2006; Menzel et al., 2004; Smedley et al., 2003; } \\
\text { Lorusso et al., 2007; Feng et al., } 2007\end{array}$ & Manual handling of patients \\
\hline Smith et al., 2006; Bos et al., 2007; Feng et al., 2007 & Force exertion \\
\hline $\begin{array}{l}\text { Engels et al., 1996; Freitag et al., 2007; Alexopoulos et al., 2006; } \\
\text { Yeung et al., 2005; Lorusso et al., } 2007\end{array}$ & Awkward postures \\
\hline Ando et al., 2000; Bos et al., 2007 & Static work \\
\hline Bos et al., 2007 & Repetitive work \\
\hline Engels et al., 1996; Ando et al., 2000 & Bending the back \\
\hline Smith et al., 2006 & Bending/twisting the back \\
\hline $\begin{array}{l}\text { Ando et al., 2000; Freitag et al., 2007; Fochsen et al., 2006; } \\
\text { Nelson et al., } 2006\end{array}$ & Transfering patients \\
\hline Fochsen et al., 2006 & Lack of equipments for transfering patients \\
\hline Alexopoulos et al., 2006 & Stressfull movements of upper limbs \\
\hline Ando et al., 2000 & Moving stretchers \\
\hline Menzel et al., 2004 & Performing risk tasks \\
\hline Ando et al., 2000 & Helping patients during the bath \\
\hline Ando et al., 2000 & Treating emergential patients \\
\hline Engels et al., 1996; Lorusso et al., 2007 & Working under time pressure \\
\hline Engels et al., 1996; Violante et al., 2004 & Very tiring work \\
\hline Smith et al., 2006 & Mental stress \\
\hline $\begin{array}{l}\text { Engels et al., 1996; Smedley et al., 2003; Alexopoulos et al., } \\
\text { 2006; Bos et al., 2007; Violante et al., 2004; Lorusso et al., } 2007\end{array}$ & High demand of work \\
\hline Ando et al., 2000 & Difficulty on reducing work demand \\
\hline Lipscomb et al., 2002; Trinkoff et al., 2006 & Long workday \\
\hline Sveinsdottir, 2006; Trinkoff et al., 2006 & Work shift (night, rotative, weekend) \\
\hline Trinkoff et al., 2006 & Working over shift \\
\hline Violante et al., 2004 & Working time in career \\
\hline Engels et al., 1996 & Insufficient breaks/pauses \\
\hline Ando et al., 2000 & Unplanned work \\
\hline $\begin{array}{l}\text { Smedley et al., 2003; Alexopoulos et al., 2006; Bos et al., 2007; } \\
\text { Lorusso et al., } 2007\end{array}$ & Low job control \\
\hline Ando et al., 2000 & Extra work due to poor physical condition of colleagues \\
\hline Kjellberg et al., 2003 & Poor job technique \\
\hline Kjellberg et al., 2003 & Lack of regular training \\
\hline Engels et al., 1996; Bos et al., 2007 & Poor ergonomic layouts \\
\hline Smedley et al., 2003; Lorusso et al., 2007 & Work dissatisfaction \\
\hline Smedley et al., 2003 & Low support at work \\
\hline Lorusso et al., 2007 & Job insecurity \\
\hline Lorusso et al., 2007 & Low professional recognition \\
\hline Lorusso et al., 2007 & Work environment \\
\hline Feng et al., 2007 & Psychological demand \\
\hline
\end{tabular}


Among biomechanical factors, the main risk activities are related to force exertion $[6,10,11]$, manual handling of patients $[1,6,10,21,29]$, awkward postures $[1,12,22,36,41]$, transferring of patients $[3,17,34,36]$, lifting heavy equipments $[12,22,34,41]$, working in static positions [11,34], and bending/twisting the back $[10,22,34]$.

Some studies associated environmental aspects such as poor ergonomic layouts [11,22] and lack of equipments [17] to the development of musculoskeletal symptoms.

Researchers also found out organizational problems in nursing workday, such as repetitive tasks [11], long workday $[4,23]$, work shifts $[4,20]$, insufficient pauses [22], and lack of training [26].

Risk factors related to psychosocial aspects were found by researchers concerned with nursing personnel, such as high perceived workload $[1,11,12,16,21,22]$, time pressure $[1,10,22]$, low job control $[1,11,12,21]$, and low job satisfaction $[1,21]$.

Regarding the literature review about other measuring instruments, it was found the use of generic questionnaires for evaluation of several disorders among nursing personnel. Depression, emotional fatigue, musculoskeletal symptoms, burnout, sleep quality are some of the problems evaluated using generic questionnaires $[2,5-8,11,14,15,19,28,30-$ $32,37-40,42,43]$.

It was also found that some psychosocial aspects in nursing have been assessed by specific questionnaires [18,25,33,35].

In contrast, it was found a lack of measurement tools for analysis of job factors that can lead to musculoskeletal symptoms specially developed for nursing personnel.

\section{Discussion and conclusions}

There is no unique cause for developing musculoskeletal disorders but many job factors that can contribute to them [27]. The results of this literature review showed that nursing personnel are exposed to many types of job factors, such as biomechanical, environmental, organizational, and psychosocial factors.

It is important to study the relationship between the occurrence of musculoskeletal symptoms and job factors [24]. A questionnaire developed specially for nursing personnel can assist the ergonomic analysis of their workplaces to prevent musculoskeletal disorders and the periodic evaluation of their activities.
The results of the present study showed that many aspects have to be considered to developing a new questionnaire. Analyzing and selecting the main job factors related to musculoskeletal symptoms is, therefore, the first step to elaborate the specific instrument for nursing personnel.

Additional steps are necessary to elaborate the new questionnaire. During the development of the domains and selection of items of the questionnaire, the results of the literature review is combined with interviews with a sample of the nursing team. Then, a content validity is performed by experts in the field and a pretest must be applied in a sample of subjects. After all changes made during these steps, the questionnaire is applied to a large number of nursing personnel to verify its reliability and validity.

In conclusion, the development of a specific questionnaire for evaluating the job factors that may contribute to musculoskeletal symptoms in nursing personnel is unprecedented, and this literature review points out some important risk activities that may be considered during the development of this questionnaire.

\section{References}

[1] A. Lorusso, S. Bruno, N. L'abbate, A review of low back pain and musculoskeletal disorders among Italian nursing personnel, Ind Health 45 (2007), 637-644.

[2] A. Markaki, A. Alegakis, N. Antonakis, A. KalokerinouAnagnostopoulou, C. Lionis, Exploring training needs of nursing staff in rural Cretan primary care settings, Appl Nurs Res 22 (2009), 138-143.

[3] A. Nelson, M. Matz, F. Chen, K. Siddharthan, J. Lloyd, G. Fragala, Development and evaluation of a multifaceted ergonomics program to prevent injuries associated with patient handling tasks, Int J Nurs Stud 43 (2006), 717-733.

[4] A.M. Trinkoff, R. Le, J. Geiger -Brown, J. Lipscomb, G. Lang, Longitudinal relationship of work hours, mandatory overtime, and on-call to musculoskeletal problems in nurses, Am J Ind Med 49 (2006), 964-971.

[5] A.P. Dawson, E.J. Steele, P.W. Hodges, S. Stewart, Development and test-retest reliability of an extended version of the Nordic Musculoskeletal Questionnaire (NMQ-E): a screening instrument for musculoskeletal pain, J Pain 10 (2009), 517526.

[6] C.K. Feng, M.L. Chen, I.F. Mao, Prevalence of and risk factors for different measures of low back pain among female nursing aides in Taiwanese nursing homes, BMC Musculoskelet Disord 8 (2007).

[7] D. Camerino, P.M. Conway, B.I.J.M. van der Heijden, M. Estryn-Béhar, G. Costa, H.M. Hasselhorn, Age-dependent relationships between work ability, thinking of quitting the job, and actual leaving among Italian nurses: A longitudinal study, Int J Nurs Stud 45 (2008), 1645-1659.

[8] D. Camerino, P.M. Conway, S. Sartori, P. Campanini, M. Estryn-Béhar, B.I.J.M. van der Heijden, G. Costa, Factors af- 
fecting work ability in day and shift-working nurses, Chronobiol Int 25 (2008), 425-442.

[9] D.C. Cole, A.S. Ibrahim, H.S. Shannon, F. Scott, J. Eyles, Work correlates of back problems and activity restriction due to musculoskeletal disorders in the Canadian national population health survey (NPHS) 1994-5 data, Occup Environ Med 58 (2001), 728-734.

[10]D.R. Smith, M. Mihashi, Y. Adachi, H. Koga, T. Ishitake, A detailed analysis of musculoskeletal disorder risk factors among Japanese nurses, J Safety Res 37 (2006), 195 - 200.

[11]E. Bos, B. Krol, L. van der Star, J. Groothoff, Risk factors and musculoskeletal complaints in non-specialized nurses, IC nurses, operation room nurses, and X-ray technologists, Int Arch Occup Environ Health 80 (2007), 198-206.

[12]E.C. Alexopoulos, A. Burdorf, A. Kalokerinou, A comparative analysis on musculoskeletal disorders between Greek and Dutch nursing personnel, Int Arch Occup Environ Health 79 (2006), 82-88.

[13]E.C. Alexopoulos, I.C. Stathi, F. Charizani, Prevalence of musculoskeletal disorders in dentists, BMC Musculoskeletal Disorders 5 (2004).

[14]F. Al-Kandari and D. Thomas, Adverse nurse outcomes: correlation to nurses' workload, staffing, and shift rotation in Kuwaiti hospitals, Appl Nurs Res 21 (2008), 139-146.

[15]F. Herin, C. Paris, A. Levant, M.C. Vignaud, A. Sobaszek, J.M. Soulat, ORSOSA group, Links between nurses' organisational work environment and upper limb musculoskeletal symptoms: Independently of effortreward imbalance! The ORSOSA study, Pain 152 (2011) 2006-2015.

[16]F.S. Violante, M. Fiori, C. Fiorentini, A. Risi, G. Garagnani, R Bonfiglioli, S. Mattioli, Associations of psychosocial and individual factors with three different categories of back disorder among nursing staff, J Occup Health 46 (2004), 100-108.

[17] G. Fochsen, M. Josephson, M. Hagberg, A. Toomingas, M. Lagerström, Predictors of leaving nursing care: a longitudinal study among Swedish nursing personnel, Occup Environ Med 63 (2006), 198-201.

[18]H. Ozturk, S. Sokmen, F. Yılmaz, D. Cilingir, Measuring mobbing experiences of academic nurses: Development of a mobbing scale, J Am Acad Nurse Pract 20 (2008), 435-442.

[19]H. Sveinsdóttir and H.K. Gunnarsdóttir, Predictors of selfassessed physical and mental health of Icelandic nurses: Results from a national survey, Int J Nurs Stud 45 (2008), 14791489.

[20]H. Sveinsdóttir, Self-assessed quality of sleep, occupational health, working environment, illness experience and job satisfaction of female nurses working different combination of shifts, Scand J Caring Sci 20 (2006), 229-237.

[21] J. Smedley, F. Trevelyan, H. Inskip, P. Buckle, C. Cooper, D. Coggon, Impact of ergonomic intervention on back pain among nurses, Scand J Work Environ Health 29 (2003), 117 123.

[22] J.A. Engels, J.W.J. van der Gulden, T.F. Senden, B. van't Hof, Work related risk factors for musculoskeletal complains in the nursing profession: results of a questionnaire survey, Occup Environ Med 53 (1996), 636-641.

[23] J.A. Lipscomb, A.M. Trinkoff, J. Geiger-Brown, B. Brady, Work-schedule characteristics and reported musculoskeletal disorders of registered nurses, Scand J Work Environ Health 28 (2002), 394-401.

[24]J.C. Rosecrance, T.M. Cook, C.L. Zimmermann, Test-retest reability of a self-administered musculoskeletal symptoms and job factors questionnaire used in ergonomics research, Appl Occup Environ Hyg 17 (2002), 613-621.
[25]J.M. Augusto Landa, E. López-Zafra, M.P.B. Martos, M.C. Aguilar-Luzón, The relationship between emotional intelligence, occupational stress and health in nurses: A questionnaire survey, Int J Nurs Stud 45 (2008), 888-901.

[26]K. Kjellberg, M. Lagerstrom, M. Hagberg, Work technique of nurses in patient transfer tasks and associations with personal factors, Scand J Work Environ Health 29 (2003), 468-477.

[27]L. Punnett and D.H. Wegman, Work-related musculoskeletal disorders: the epidemiologic evidence and the debate, J Electromyogr Kinesiol 14 (2004), 13-23.

[28] M. Takahashi, K. Iwakiri, M. Sotoyama, M. Hirata, N. Hisanaga, Musculoskeletal pain and night-shift naps in nursing home care workers, Occup Med 59 (2009), 197-200.

[29] N.N. Menzel, S.M. Brooks, T.E. Bernard, A. Nelson, The physical workload of nursing personnel: association with musculoskeletal discomfort, Int J Nurs Stud 41 (2004), 859867.

[30]P. Meadors and A. Lamson, Compassion fatigue and secondary traumatization: provider self care on Intensive Care Units for children, J Pediatr Health Care 22 (2008), 24-34.

[31]P. Meijsen and H.J.J. Knibbe, Work-related musculoskeletal disorders of perioperative personnel in the Netherlands, AORN J 86 (2007), 193-208.

[32]P. Schenk, T. Läubli, J. Hodler, A. Klipstein, Symptomatology of recurrent low back pain in nursing and administrative professions, Eur Spine J 16 (2007), 1789-1798.

[33]R. Pisanti, C. Lombardo, F. Lucidi, D. Lazzari, M. Bertini, Development and validation of a brief Occupational Coping Self-Efficacy Questionnaire for Nurses, J Adv Nurs 62 (2008), 238-247.

[34] S. Ando, Y. Ono, M. Shimaoka, S. Hiruta, Y. Hattori, F. Hori et al., Associations of self estimated workloads with musculoskeletal symptoms among hospital nurses, Occup Environ Med 57 (2000), 211-216.

[35]S. Berg, L. Dahl, O. Dehlin, B. Hedenrud, Psychological perception of nursing aides' work, Scand J Rehab Med 8 (1976), 79-84.

[36]Freitag, R. Ellegast, M. Dulon, A. Nienhaus, Quantitative measurement of stressful trunk postures in nursing professions, Ann Occup Hyg 51 (2007), 385-395.

[37] S. Karagozoglu and N. Bingöl, Sleep quality and job satisfaction of Turkish nurses, Nurs Outlook 56 (2008), 298-307.

[38] S. Kim, L.M. Barker, B. Jia, M.J. Agnewa, M.A. Nussbaum, Effects of two hospital bed design features on physical demands and usability during brake engagement and patient transportation: A repeated measures experimental study, Int J Nurs Stud 46 (2009), 317-325.

[39] S. Stucke and N.N. Menzel, Ergonomic assessment of a critical care unit, Crit Care Nurs Clin North Am 19 (2007), 155165.

[40] S.J. Cameron, M. Armstrong-Stassen, D. Kane, F.B.P. Moro, Musculoskeletal problems experienced by older nurses in hospital settings, Nurs Forum 43 (2008), 103-114.

[41]S.S. Yeung, A. Genaidy, J. Deddens, S. Sauter, The relationship between protective and risk characteristics of acting and experienced workload, and musculoskeletal disorder cases among nurses, J Safety Res 36 (2005), 85-95.

[42] T. Mitchell, P.B. O’Sullivan, A.F. Burnett, L. Straker, C. Rudd, Low back pain characteristics from undergraduate student to working nurse in Australia: A cross-sectional survey, Int J Nurs Stud 45 (2008), 1636-1644.

[43]T. Szczurak, B. Kamińska, A. Szpak, Estimation of the psychological load in the performance of nurses' work based on subjective fatigue symptoms, Adv Med Sci 52 Suppl (2007), 102-104. 
[44]U. Aasa, M. Barnekow-Bergkvist, K.A. Ängquist, C. Brulin, Relationships between work-related factors and disorders in the neck-shoulder and low back region among female and male ambulance personnel, J Occup Health 47 (2005), 481489.
[45]Y. Salik and A. Özcan, Work-related musculoskeletal disorders: a survey of physical therapists in Izmir - Turkey, BMC Musculoskeletal Disorders 5 (2004). 